\title{
A COMPARATIVE STUDY OF EFFECTIVENESS OF NON STATUTORY EMPLOYEE WELFARE MEASURES WITH SPECIAL REFERENCE TO HOUSING FACILITY IN SUGAR MILLS IN KRISHNA DISTRICT OF ANDHRA PRADESH
}

\author{
M Srinivasa Rao $^{1}$ \& G. Vidyanath ${ }^{2}$
}

\begin{abstract}
Well being is the actions of advertising the performance of employee. The various welfare actions offered by the employer will have immediate effect on the health, actual and mental performance, performance, spirits and overall performance of the worker and thereby leading to the greater efficiency. The basic recommend of employee welfare is to enhance the life of employees and to keep them satisfied and performed. The reason for the study was to find out increase of usage of Employee welfare facility by the employees. The style used in the venture is illustrative kind. The systematic device used in laptop computer is amount research. From the choosing the research determine that the Employee welfare facilities are offered effectively, in inclusion to that the research suggested some ways to increase the welfare features. Some of the employee's recommendations are to increase the healthcare features and canteen features. Here, the specialist determines that Sakthi Sugars is one of the best companies in offering features to employees. Therefore, he have taken up a research on employee welfare at SAKTHI SUGARS LTD., APPAKUDAL and wish that this research will be useful to the research and to the market for satisfying their employees in the upcoming period.
\end{abstract}

Keywords- Employee's Satisfaction, MCL, Non - Statutory, Statutory, Welfare Measure

\section{INTRODUCTION}

Among the many resources needed by an economic activity, the important ones are Men, Material, Money and Machinery. Of these, the first one, i.e., men, is living one, and the other three are non-living. It is the 'men', who make use of the other non-human resources. Hence, men are the most significant resources in any organization and they make all the difference. L.F. Urwick ${ }^{1}$ had remarked that "business houses are made or broken in the long-run not by markets or capital, patents, or equipments, but by men". According to Peter F Drucker " "Man, of all the resources available, can grow and develop."

Besides being living, human resources differ from non-human resources in other respects also. Human resources are heterogeneous, in the sense, that they differ in personality, perception, emotions, values, attitudes, motives and modes of thoughts. Their behavior to stimuli is often inconsistent and unpredictable. While other resources depreciate, human resources appreciate with the passage of time. Better educated, more skilled, better aware of their interest and rights are also some distinguishing features of modern human resources. These make it difficult for managers to use human resources always in an effective and efficient manner. Given the highly competitive and complex business environment, attracting and retaining qualified and competent employees have become a real challenge of the day for the managers. The 'rule of thumb' has become obsolete and redundant. The need of the new perspective is to have right people for right jobs. This mantra offers organizations an edge, which management experts term as 'competitive advantage' or 'core competency' to survive and thrive in the competitive business environment. The same gives genesis to the concept of HRM in business organizations.

Whether at National level or Organization level the Men or Human resources are considered to be the most precious of all resources. At national level the human resource is made up of the patriotism towards their nation, the spirit of nation building, their philosophy towards life, knowledge, skills, creative abilities, talents, attitudes, etc.,.of the people.At an organisation level, human resources represent the people at work, their inherent abilities, acquired knowledge and skills as exemplified in the talents and aptitudes of its employees. In short, the human resources in an organization represent the qualitative and quantitative measurement of the workforce required in an organization. Michel J Jucius refers to Human resources to a whole consisting of inter-related, independent and interacting physiological, psychological, sociological and ethical components. Irrespective of the level, the welfare of the human resources has to be taken care of as they can only develop either a nation or an organization.

\footnotetext{
${ }^{1}$ Research Scholar, Registration No: PP MAN - 0776, Rayalaseema University, Kurnool, AP, India.

${ }^{2}$ Professor, Dept of Management Study, IPE Usmania University, Telangana, India.
} 


\section{REVIEW OF LITERATURE ON LABOUR WELFARE}

Prayag Metha (1985) undertook a case Study of Central Welfare Organizations which are meant for the purpose of administering welfare funds created in India to provide employee welfare facilities with a view to improve the quality of organized and scattered employees like those in mica, iron and manganese ore mines and beedi industry. The study was undertaken to assess the effectiveness of the programmes for improving living standards and quality of life of the concerned employees, to find out the extent and needs at the various employee welfare programmes and to identify organizational and management problems related to the functioning of various welfare activities. The study identified the need for developing and integrated community health approach in various activities like family planning, nutrition and the need for appropriate programmes for employee welfare personnel including medical personnel. According to this study, the housing and educational programmes indicated very little coverage and as such need for more vigorous and innovative program was felt necessary. In regard to the employee welfare organization, this studied concluded that they needed urgent reorientation and reorganization with proper administration, organizational structure and management.

A study conducted by Saiyadin (1989) examined the purpose and the cost of non- statutory employee welfare activities for the organizations. Five public and six private sector organizations were selected for the study. The study brought of an important conclusion that the most pre-dominant theme in the minds of organization, when they think of the voluntary employee welfare measures were not output and efficiency, but increasing loyalty and morale. In respect of the study revealed that the public sector organizations spend more on employee welfare activates, as compared to private sector organizations. While public sectors spent more on transportation and recreation, private sector was found to be spending more on housing according to this study.

Bhattacharya (1978) made a comparative analysis of the different phases of social security measures in India and in other developed countries. He concluded that the social security measures introduced in India suffer from glaring gasp and the efforts of the government and the other employers were not coordinated. The study found that the Government had taken up the question of protecting the interests of labour and had enacted a number of labour legislations in the post independence era, a big gap did exist between the policy and its implementation. He suggested that the Government of India should set up a research centre for an analytical study of the social security measures for millions of employees in the country on the field, in the factories and in the mines.

Zeheeruddin (1985) covered the various problems faced by the beedi and cigar employees/employees and the legislative and administrative steps taken to ensure a better life to toiling employees. Relevant statutes, their interpretation by the court and the actual effect of them on the life of beedi employees constituted the main part of the study. In regard to employee welfare measures the study concluded that there were great variations in the employee welfare measures and the activities of employee welfare organizations form stat to state and from industry to industry and the inspection and supervision of such activities are not very satisfactory. He suggested some measure of uniformity in such actives and a definite standard of minimum welfare should be laid down besides the effective machinery supervising the welfare activities.

Vishwan had studied the problems of sugar mill industry in Mumbai in respect of health, safety and working conditions. Verma Promod (1973) conducted a study on employees' needs and welfare in Ahmadabad, an important textile city in India. The study concluded that, the housing conditions were bad and that the felt need of the employees/employees was particularly related to such facilities as sanitation, primary schools, co-operative housing society and vocational education.

According to a study conducted by Koshal (1975) despite statutory provisions and enforcing agencies in India, the employee welfare facilities were absent and cement industry was the only industry where provisions were adequately enforced. The study suggested the need for overhauling and tightening the machinery of inspection. Appointment of welfare inspectors for different factories, distinguishing the duties of factory inspectors from those of welfare inspectors and the duties of employee welfare officers from those of welfare inspectors, requiring the employee welfare inspectors to submit annual and quarterly reports and empowering the employee welfare inspector to fine, in case of default, were some of the steps suggested in the study.

The study of Hrishikesh (1974) was concerned with the development and social security in the context of economic backwardness and the elements of economic development. Special attention was paid to the problem of Uttar Pradesh.

A study on participation of employees/employees in welfare work by Murthy and Narayana, examined the extent of participation of employees/employees in employee welfare policy formulation, programme formulation and implementation, level of assuming responsibility for administering the programmes and participation at the levels of assessment of results. The study was confined to the employees/employees in various factories in Visakhapatnam District of Andhra Pradesh.

A study on labour welfare work in Jamshedpur was undertaken by Verma (1971) which observed that various agencies of labour employee welfare had made attempts, on a partial scale, to improve the recreation, working and living conditions for the employees/ employees engaged in the various industrial organizations.

The research work of Misra (1971) aimed at sociological analysis of the labour welfare problems of sugar industry. The analysis was based on the first hand data collected from the sugar factories of Eastern Uttar Pradesh. The study concluded that the conditions of work in sugar factories of UP were not very satisfactory, particularly in respect of safety measures, 
cleanliness, sanitation, latrine facilities, drinking water, rest shelters etc. It also pointed out that provisions for leaves and holidays, lighting, housing, medical care and education were far from satisfactory.

The study of Zachariah (1954) based on the sample survey of manufacturing undertaking in Mumbai, covered employee welfare services and working conditions while surveying the factories effecting industrial relations. The study observed that, better working conditions and adequate provision of employee welfare services would contribute much for harmonious industrial relations.

The Survey conducted by the Labour Bureau 1961, showed a good awareness on the part of the employers in the jute industry in improving employee welfare amenities to the employees and their children in the education. The survey revealed that the facilities extended by them are over and above the obligation last on employers under various firms.

The article published by Loen (2009) said that it is the responsibility of an employer to improve compliance and due diligence. Apart from operational risk the employer have legal and financial justification for monitoring welfare. To measure welfare conditions the employer need to adopt a structured approach through benchmarking standards. As the employer you are held liable for employee welfare.

In an article by Shareen Aguilar (2007) about restaurant management and restaurant operations techniques said how to handle employees through owning and managing a restaurant for business isn't all about how operating it flawlessly should be done. As the highest person in-charge of establishment, the employer need to consider all areas of how employer establishment could work efficiently. Having said this, employees' welfare already counts greatly as one of the areas of consideration the employer should never overlook or take for granted. Managers aren't exempted. The things applied to employees are still the same things that managers need and in giving those perks or rewards, go for something that they'd really be looking forward.

The article of S.Shiny Nair (2009) about 'employee welfare' says that employee welfare as "efforts to make life worth living for workmen." These efforts have their origin either in some statute formed by the state or in sum local custom or in collective agreement or in the employer's own initiative.

The importance of Employee welfare measures needs no emphasis as they are essentials to motivate the work force to discharge their duties effectively. Providing adequate employee-welfare measures involves continuous improvement of employees, and their capabilities and the quality of their life. Labour welfare measures are also undertaken with a view to building up better relations with employees. Labour welfare has become a very wider subject; both comprehensive and controversial, whether in private or public sector. Unfortunately, the welfare measures undertaken today by the manufacturing organization were looked upon as charity for the poor in earlier days. However, every organization wants to make its labour force effective by providing statutory and non-statutory employee welfare measures. Implementation of Employee welfare measures vary from industry to industry, or geographical area to geographical area and from time to time. In this research paper an attempt is being made to evaluate the effectiveness of canteen facilities provided as an employee welfare measure in the sample Sugar mills in Krishna District of Andhra Pradesh.

\section{THE OBJECTIVES OF THE STUDY}

The main objectives of the present study are:

1. To study the canteen facilities provided by the sample sugar mills in Krishna District of Andhra Pradesh;

2. To critically evaluate the effectiveness of the canteen facilities provided by the sample sugar mills by measuring the satisfaction levels of the sample employee respondents;

3. To offer suggestions in the light of findings for improvement of the canteen facilities in the sample sugar mills.

\section{METHODOLOGY}

Survey method of research was adopted. The required data was collected from, both, primary and secondary sources. The primary sources of data included interviewing the employees including both officers and employees, working in the sample sugar mills and also administering separate structured schedules of questions on them. The secondary sources of data included referring to different published data like, Reports of Planning Commission, Labour Welfare Committee, Hand Book of R.B.I., Hand Book of Statistics- Krishna: 2015-16, articles, standard text books, journals, magazines and various related websites.

\subsection{Hypotheses}

The present research paper is based on the following hypothesis

Hypothesis

- Null Hypothesis $\left(\mathrm{H}_{0}\right)$ : There is no significant association between Age of the sample employee respondents and the level of satisfaction with regards to Housing Facility Scheme provided by the select Sugar Mills in Krishna District.

- Alternative Hypothesis $\left(\mathrm{H}_{1}\right)$ :There issignificant association between Age of the sample employee respondents and the level of satisfaction with regards to Housing Facilities provided by the select Sugar Mills in Krishna District. 


\section{RATIONALE IN SELECTION OF KRISHNA DISTRICT}

The Krishna District is one of the major sugarcane producing areas in Andhra Pradesh. Nearly 260 villages participate in producing the sugarcane. K.C.P Sugar and Industries Corporation Limited, Vuyyuru, K.C.P Sugar and Industries Corporation Limited, Lakshmipuram, and Delta Sugars Limited (Formerly known as Sree Hanuman Co-operative sugars Limited) are major sugar producing mills in Krishna District of Andhra Pradesh. Therefore, the present research paper is an attempt in evaluating the adequacy, implementation, satisfaction levels of the sample employee respondents regarding the canteen facilities provided by the sample sugar mills in Krishna District of Andhra Pradesh.

\subsection{Sampling}

The present research paper covers all the above three major manufacturers of sugar in Krishna District of Andhra Pradesh. The employee respondents include, both officer and worker, were selected on random basis with stratified multi-stage sample technique. In each mill, one-fourth of total employees were selected on random basis for collecting the required data. Therefore, out of total employees of 1,624 in all the three mills, a sample of 406 employees taken as the sample respondents.

\subsection{Tools for Collection of the data}

Separate structured schedules of questions were prepared and administered over the sample officer and worker respondents of the select sugar mills to gather the information regarding implementation and effectiveness of the canteen facilities.

\subsection{Tools for Analysis of Data}

Appropriate mathematical and statistical tools, like, percentages, averages, etc., were used for analyzing the data collected. Chi-square test was also used for testing the association between the Age of the sample employee respondents and their satisfaction levels with regards to canteen facilities in the sample sugar mills in Kishna District of Andhra Pradesh.

\subsection{Limitations of the Study}

The present research work suffered from the following important limitations:

1. The 'TIME' was major constraint as the Sample Employee Respondents could not spare sufficient time to answer the schedules of questions;

2. The 'BIAS' of the sample employee respondents in answering the questions was another important limitation.

3. The matter of "CONFIDENTIALITY"on certain issues restricted information sharing by the Sample Employee Respondents.

\section{PATTERNS OF NON-STATUTORY WELFARE ACTIVITIES AT THE SELECT SUGAR MILLS}

Besides the Statutory Welfare measures/activities, a few Non-Statutory welfare programmes are expected by the Indian workers and employeesto be provided by the Indian employers. Here an attempt has been made to study the various nonstatutory welfare amenities provided by the select Sugar mills under the present study. Some of the non-statutory welfare measure provided by the select sugar mills, include, housing, travelling, medical, cooperative consumer stores, cooperative credit society, education, productivity incentive facilities, entertainment, maternity leave facility, Leave travel facility, free power and water facilities, etc.,

\subsection{Housing}

Among the basic necessities for living, housing is very significant that comes next to food and clothing. Housing being basic necessity as also rightly pointed out by the Committee on Labour Welfare needs a very high priority in any scheme of national planning and industrial development. In developing countries like India, housing has been a social problem affecting all sections of population in some way or other. Since the health and efficiency of employees of an organization are directly affected by the type of houses they live in, inadequate and poor quality of housing, development of slums around the industrial area are considered to by the attendant evils of industrialization. Provision of cheap, healthy and adequate accommodation will result in the good health and efficiency of employees. It may be mentioned that the healthy accommodation includes adequate space, ventilation, lighting, latrines, drainage and other sanitary arrangements. Thus, housing should not be considered to be a mere accumulation of bricks and sand in a symmetrical form. At this juncture, K.N.Vaid has rightly remarked that,A house is not just a roof over four walls or a place to sleep and take shelter; it is an extension of human personality.

The Royal Committee on Labour also remarked that the inadequate and poor quality of housing is the bane of urban industrial life. It further commented that in every industrial country the problem associated with the housing of the working classes have increased as industry has developed and India is not an exception to that rule. The Labour Investigation Committee which reviewed the housing conditions in various urban areas of India felt that, A clear long term housing policy was essential for improving housing conditions of industrial employees. 
In spite of serval schemes, housing continuous to be a problem because ofindustrialization, urbanization and migration. The capacity of employees has been limited. Toraise resource to solve this problem by themselves. As such, employers have got a role to play in providing housing facilities to their employees on their own accord. Further the role of co-operative societies in providing houses to their employees has helped them in a marginal way.

The different types of housing facilities are available around the select sugar mills (see Table 1.1). All the types of quarters are provided with one bed room, one drawing room, one kitchen and verandah. These quarters are allotted to workmen of various categories. Electricity is supplied free of cost to certain limit depending upon the grades of the employee/worker. For highly skilled and skilled-II categories of employees 50 units of free electricity is allowed while for skilled -I and semiskilled, it is 30 units. One rupee and fifty paisa per unit is charged and above the free units of electricity consumed. The allotment is based on seniority as well as necessity and the rent charged to various categories of employees is as followed:

\section{Category \\ High skilled \\ Skilled - II \\ Skilled - I \\ Semi - skilled \\ Unskilled}

\section{Rent Charges}

Rs. 250 per month

Rs. 200 per month

Rs. 180 per month

Rs. 150 per month

Rs. 120 per month

Those who do not stay in the company quarters will be paid the house rent allowance as above

Table - 1.1 Statement showing Different types of Housing facilities at the select Sugar Mills

\begin{tabular}{|c|c|c|c|}
\hline $\begin{array}{l}\text { Quarter's } \\
\text { Type }\end{array}$ & KCP Vuyyuru Unit & KCP Lakshmipuram Unit & Delta Sugars limited \\
\hline B-1 Type & $\begin{array}{l}\text { Pucca Building - } 2 \\
\text { blocks, Consisting of } 4 \\
\text { portions in each block }\end{array}$ & $\begin{array}{l}\text { Pucca Building - } 2 \text { blocks, } \\
\text { Consisting of } 4 \text { portions in } \\
\text { each block }\end{array}$ & $\begin{array}{l}\text { Pucca Building }-2 \text { blocks, } \\
\text { Consisting of } 4 \text { portions in each } \\
\text { block }\end{array}$ \\
\hline В-2 Туре & $\begin{array}{l}\text { Pucca Building - } 2 \\
\text { blocks, Consisting of } 3 \\
\text { portions in each block }\end{array}$ & $\begin{array}{l}\text { Pucca Building - } 2 \text { blocks, } \\
\text { Consisting of } 3 \text { portions in } \\
\text { each block }\end{array}$ & $\begin{array}{l}\text { Pucca Building }-2 \text { blocks, } \\
\text { Consisting of } 3 \text { portions in each } \\
\text { block }\end{array}$ \\
\hline B-3 Type. & $\begin{array}{l}\text { Pucca Building - } 1 \\
\text { blocks, Consisting of } 2 \\
\text { portions in each block }\end{array}$ & $\begin{array}{l}\text { Pucca Building - } 1 \text { blocks, } \\
\text { Consisting of } 2 \text { portions in } \\
\text { each block }\end{array}$ & $\begin{array}{l}\text { Pucca Building - 1blocks, } \\
\text { Consisting of } 2 \text { portions in each } \\
\text { block }\end{array}$ \\
\hline B-4 Type & $\begin{array}{l}\text { Pucca Building - } \\
\text { 1blocks, Consisting of } \\
2 \text { portions in each block }\end{array}$ & $\begin{array}{l}\text { Pucca Building - } 1 \text { blocks, } \\
\text { Consisting of } 2 \text { portions in } \\
\text { each block }\end{array}$ & $\begin{array}{l}\text { Pucca Building }-1 \text { blocks, } \\
\text { Consisting of } 2 \text { portions in each } \\
\text { block }\end{array}$ \\
\hline C-1 Type. & $\begin{array}{l}\text { Pucca with asbestos } \\
\text { roofing } 25 \text { blocks, } \\
\text { Consisting of } 10 \\
\text { portions in each block }\end{array}$ & 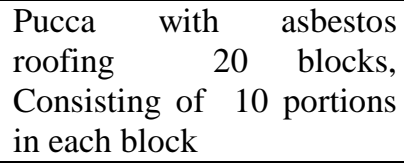 & $\begin{array}{l}\text { Pucca with asbestos roofing } 32 \\
\text { blocks, Consisting of } 4 \text { portions } \\
\text { in each block }\end{array}$ \\
\hline C-2 Type & $\begin{array}{l}\text { Pucca Building - } 58 \\
\text { blocks, Consisting of } 2 \\
\text { portions in each block }\end{array}$ & $\begin{array}{llr}\text { Pucca Building }- & 20 \\
\text { blocks, Consisting of } & 2 \\
\text { portions in each block } & \end{array}$ & $\begin{array}{l}\text { Pucca Building - } 30 \text { blocks, } \\
\text { Consisting of } 2 \text { portions in each } \\
\text { block }\end{array}$ \\
\hline C-3 Type. & $\begin{array}{l}\text { Pucca with asbestos } \\
\text { roofing } 28 \text { blocks, } \\
\text { Consisting of } 10 \\
\text { portions in each block }\end{array}$ & 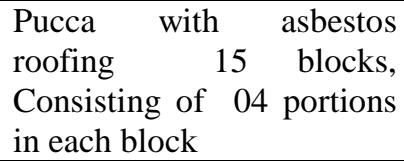 & $\begin{array}{ll}\text { Pucca with asbestos roofing } & 32 \\
\text { blocks, Consisting of } & 06 \\
\text { portions in each block }\end{array}$ \\
\hline Dormitory & $\begin{array}{l}\text { Available for } 20 \\
\text { bachelors, each block } \\
\text { containing with one bed } \\
\text { room and small } \\
\text { verandah }\end{array}$ & $\begin{array}{l}\text { Available for } 15 \text { bachelors, } \\
\text { each block containing with } \\
\text { one bed room and small } \\
\text { verandah }\end{array}$ & $\begin{array}{l}\text { Available for } 10 \text { bachelors, each } \\
\text { block containing with one bed } \\
\text { room and small verandah }\end{array}$ \\
\hline
\end{tabular}


7. AN ANALYSIS OF OPINION OF THE SAMPLE EMPLOYEE RESPONDENTS REGARDING THE HOUSING FACILITIES PROVIDED BY THE SELECT SUGAR MILLS

When the opinion of the sample employee respondents regarding the housing facilities provided by the select sugar mills is analyzed, we find that out of 406 Sample Employee Respondents, 26 Sample Employee Respondents, representing 6.4 percent, feel excellent, 64 respondents, forming 15.76 percent, feel good, 125 respondents, representing 30.78 percent, feel average, 144 respondents, representing 35.46 percent, feel satisfied, and 47Sample Employee Respondents, representing 11.57 percent, feel unsatisfied (see Table 1.2).

Further, out of 406 sample employee respondents, 16 respondents are in the age group of below 20 year, 32 respondents are in the age group of 20-30 years, 85 respondents are in the age group of 30-40 years, 207 Sample Employee Respondents fall in the age group of 40-50 years, 61 respondents belong to the age group 50-60 years and the remaining 5 respondents belong to the age group of above 60 years. The age group of $40-50$ years is representing to the maximum extent of 207 respondents out of which only 14respondents feel excellent of the housing facility provided by the mills, 41 respondents feel good and 79 respondents feel average of the housing facilities provided by the mills. Generally this age group is a matured group and their opinion would be more reliable. Of this this age group 64.73 percent feel that the housing facilities provided by the select sugar mills is above satisfactory level and the remaining megre 35.27 percent feel unhappy with housing facilities and can be improved.

The Mill-wise analysis reveal that out of 26Sample Employee Respondents feeling that the housing facilities are excellent, 21 respondents are the employees of KCP Vuyyuru, and the remaining 5 belong to Delta Sugar Mills. Out of 64Sample Employee Respondents feeling that the housing facilities are good, 46 respondents are the employees of KCP Vuyyuru, 12 respondents belong to KCP Lakshmipuram, and 6 respondents are the employees of Delta Sugar Mills. Of 125Sample Employee Respondents feeling that the housing facilities are average, 38 respondents are the employees of KCP Vuyyuru, 30 respondents belong to KCP Lakshmipuram, and 57 respondents are the employees of Delta Sugar Mills.

It can be implied that though most of theSample Employee Respondents seem to be satisfied with housing facilities, some respondents feel that they can still be improved.

Chi-square test for analyzing the association between Age of the Sample Employee Respondents and the satisfaction levels with regards to the Housing Facility

provided by the Sugar Mills in Krishna District.

\subsection{Hypothesis}

- $\quad$ Null Hypothesis $\left(\mathrm{H}_{0}\right)$ : There is no significant association between Age of the sample employee respondents and the level of satisfaction with regards to Housing Facility Scheme provided by the select Sugar Mills in Krishna District.

- Alternative Hypothesis $\left(\mathrm{H}_{1}\right)$ :There issignificant association between Age of the sample employee respondents and the level of satisfaction with regards to Housing Facilities provided by the select Sugar Mills in Krishna District.

Pearson's Chi-square test - for testing the Age of the sample employee respondents and Level of Satisfaction with regards to Housing Facility provided by

KCP Sugar and Industries Corporation Limited, Vuyyuru

Pearson's Chi-square test - association between Age of the Sample Employee Respondents and Excellent level of satisfaction regarding Housing Facility

data: company.data2

$\mathrm{X}$-squared $=6, \mathrm{df}=5, \mathrm{p}$-value $=0.3062$

Pearson's Chi-square test - association between Age of the Sample Employee Respondents and Good level of satisfaction regarding Housing Facility

data: company.data3

$X$-squared $=6, \mathrm{df}=5, \mathrm{p}$-value $=0.3062$

Pearson's Chi-square test - association between Age of the Sample Employee Respondents and Average level of satisfaction regarding Housing Facility

data: company.data4

$\mathrm{X}$-squared $=24, \mathrm{df}=20, \mathrm{p}$-value $=0.2424$

Pearson's Chi-square test - association between Age of the Sample Employee Respondents and Satisfactory level of satisfaction regarding Housing Facility

data: company.data5 
$X$-squared $=24, \mathrm{df}=20, \mathrm{p}$-value $=0.2424$

Pearson's Chi-square test - association between Age of the Sample Employee Respondents and Non-Satisfactory level of satisfaction regarding Housing Facility

data: company.data6

$X$-squared $=24, \mathrm{df}=20, \mathrm{p}$-value $=0.2424$

When Chi-square test is applied to test the association between Age of Sample Employee Respondents and level of Satisfaction regarding the housing facilities provided by KCP Sugar and Industries Corporation Limited, Vuvvuru, we find that the $\mathrm{p}$ value is greater than 0.05 at all levels of satisfaction. Therefore null hypothesis would be accepted indicating that there is no relationship between Age of the sample employee respondents and their level of satisfaction regarding the housing facilities provided by KCP Vuyyuru.

Pearson's Chi-square test - for testing the Age of the sample employee respondents and Levels of Satisfaction with regards to Housing Facility provided by KCP Sugar and Industries Corporation Limited, Lakshmipuram

Pearson's Chi-square test - association between Age of the Sample Employee Respondents and Excellent level of satisfaction regarding Housing Facility

data: company.data2

$X$-squared $=0, \mathrm{df}=5, \mathrm{p}$-value $=1$

Pearson's Chi-square test - association between Age of the sample employee respondents and Good level of satisfaction regarding Housing Facility

data: company.data3

$\mathrm{X}$-squared $=18, \mathrm{df}=15, \mathrm{p}$-value $=0.2627$

Pearson's Chi-square test - association between Age of the sample employee respondents and Average level of satisfaction regarding Housing Facility

data: company.data4

$\mathrm{X}$-squared $=18, \mathrm{df}=15, \mathrm{p}$-value $=0.2627$

Pearson's Chi-square test - association between Age of the sample employee respondents and Satisfactory level of satisfaction regarding Housing Facility

data: company.data5

$\mathrm{X}$-squared $=30, \mathrm{df}=25, \mathrm{p}$-value $=0.2243$

Pearson's Chi-square test - association between Age of the Sample Employee Respondents and Non-Satisfactory level of satisfactory regarding Housing Facility

data: company.data6

$\mathrm{X}$-squared $=18, \mathrm{df}=15, \mathrm{p}$-value $=0.2627$

When Chi-square test is applied to test the association between Age of Sample Employee Respondents and level of Satisfaction regarding the housing facilities provided by KCP Sugar and Industries Corporation Limited, Lakshmipuram, we find that the p value is greater than 0.05 at all levels of satisfaction. Therefore, the null hypothesis would be accepted indicating that there is no relationship between Age of the Sample Employee Respondents and their level of satisfaction.

Pearson's Chi-square test - for testing the Age of the sample employee respondents and Satisfaction with regards to Housing Facility provided by Delta Sugar Mills

Pearson's Chi-square test - association between Age of the Sample Employee Respondents and Excellent level of satisfaction regarding Housing Facility

data: company.data2

$\mathrm{X}$-squared $=6, \mathrm{df}=5, \mathrm{p}$-value $=0.3062$

Pearson's Chi-square test - association between Age of the Sample Employee Respondents and Good level of satisfaction regarding Housing Facility

data: company.data3

$\mathrm{X}$-squared $=\mathrm{NaN}, \mathrm{df}=5, \mathrm{p}$-value $=\mathrm{NA}$ 
Pearson's Chi-square test - association between Age of the sample employee respondents and Average level of satisfaction regarding Housing Facility

data: company.data4

$\mathrm{X}$-squared $=24, \mathrm{df}=20, \mathrm{p}$-value $=0.2424$

Pearson's Chi-square test-association between Age of the sample employee respondents and Satisfactory level of satisfaction regarding Housing Facility

data: company.data5

$\mathrm{X}$-squared $=24, \mathrm{df}=20, \mathrm{p}$-value $=0.2424$

Pearson's Chi-square test-association between Age of the sample employee respondents and Non-Satisfactory level of satisfaction regarding Housing Facility

data: company.data6

$\mathrm{X}$-squared $=24, \mathrm{df}=20, \mathrm{p}$-value $=0.2424$

When Chi-square test is applied to test the association between Age of Sample Employee Respondents and Level of Satisfaction regarding the housing facilities provided by Delta Sugars Limited, we find that the p value is greater than 0.05 at all levels of satisfaction. Therefore, null hypothesis would be accepted indicating that there is no relationship between Age of the Sample Employee Respondents and their level of satisfaction regarding the housing facilities provided by Delta Sugar Limited..

All Levels of Satisfaction - Mill-wise Analysis

Pearson's Chi-square test - association between Age of the sample employee respondents and over-all Satisfaction regarding Housing Facility provided by KCP Sugars and Industrial Corporation Limited, Vuyyuru

data: company.data2

$\mathrm{X}$-squared $=6, \mathrm{df}=5, \mathrm{p}$-value $=0.3062$

Pearson's Chi-square test - association between Age of the sample employee respondents and over-all Satisfaction regarding Housing Facility provided by KCP Sugars and Industrial Corporation Limited, Lakshmipuram

data: company.data3

$\mathrm{X}$-squared $=\mathrm{NaN}, \mathrm{df}=5$, $\mathrm{p}$-value $=\mathrm{NA}$

Pearson's Chi-square test - association between Age of the sample employee respondents and over-all Satisfaction regarding Housing Facility provided by Delta Sugar Mills

data: company.data4

$\mathrm{X}$-squared $=24, \mathrm{df}=20, \mathrm{p}$-value $=0.2424$

Summarized Statement - Chi-square for Age and Housing Facility

\begin{tabular}{|l|l|l|l|}
\hline & KCP, Vuyyuru & KCP, Lakshmipuram & Delta Sugar Mills \\
\hline Excellent & 0.3062 & 1 & 0.3062 \\
\hline Good & 0.3062 & 0.2627 & NA \\
\hline Average & 0.2424 & 0.2627 & 0.2424 \\
\hline Satisfactory & 0.2424 & 0.2243 & 0.2424 \\
\hline Non-Satisfactory & 0.2424 & 0.2627 & 0.2424 \\
\hline Combined & 0.3062 & NA & 0.2424 \\
\hline
\end{tabular}

When we observe the association between Age of Sample Employee Respondents and Level of Satisfaction regarding the housing facilities provided by each of the select Sugar Mills, we find that the p value is greater than 0.05 in case all the select mills and therefore, the null hypothesis would be accepted indicating that there is no relationship between Age of the Sample Employee Respondents and their levels satisfaction regarding housing facilities provided by the select Mills under the study. 


\section{CONCLUSION}

The research on worker well being allows the control to know the fulfillment level of the workers about the welfare measures offered by the organization. From this research we can infer that most of the workers are pleased with the welfare actions. The organization can focus on other facilities like crèche service, consistent to increase the employee morale. The staff member spirits is good in the organization. They should take necessary actions to increase in those actions. So, that the workers can do their job more successfully.

\section{REFERENCES}

[1] Prayag Metha, Welfare of unorganized employees - The case of Central welfare organizations, Vikalpa, July - September,1985, pp.279-302.

[2] Saiyadin.S.Mirza, Voluntary Welfare in India, Lok Udyog, October - 1989, pp.29-33.

[3] V.R.Bhattacharya, Some aspects of Social Security in Indian Employees, Vol.II, 1978, pp. 131-132.

[4] Zeheeruddin, Labour welfare Laws and working conditions in India with special reference to beedi and cigar employees, Deep and Deep Publications, New Delhi, 1985,pp. 46-48.

[5] Verma Promod, Labour in TextileCity - A case study of employees, needs and welfare in India, Indian Institute of Management, Ahmadabad, 1973,pp 92-94.

[6] Koshal Manjulika, Labour Welfare in India, J.S.Uppal (ED), India's Economic Problems - an analytical approach, Tata Mc Graw Hill Publishing Company Ltd., New Delhi, 1975, pp $203-219$.

[7] Hrishikesh, Study of some aspects of Social Security in Uttar Pradesh, Lucknow University, Lucknow, 1974 , p.45.

[8] R.R. Verma, Labour Welfare Work in Jamshedpur, RanchiUniversity, Bihar, 1971, p.62.

[9] K.K.Mosra, Labour Welfare in India Industries, Meenakshi Prakasan, Meerut, 1971,p.46.

[10] Zacharaiah, Industrial Relations and Personal Problems - A study With Practical reference to Bombay, Asia Publishing House, Bombay, 1954, p.28.

[11] Labour Bureau, Report on Welfare amenities available to employees employed in Jute Industry, 1961, pp. 12-14

[12] www.articlesbase.com.

[13] www.restaurant-business-secrets.com

[14] www.articlesbase.com.

[15] www.management_issues.com

[16] www.cla.gov.tw.com.

[17] www.dostoc.com

[18] "Designing Employee Welfare Provision"- by Ann Davis, Lucy Gilbson (1994), Perssonel Review, vol., 23

[19] www.industrialrelations.naukrihub.com

[20] www.managementparadise.com

[21] www.ankitakulkarni.com

[22] www.healthtips24.com

[23] www.industrialrelations.naukrihub.com

[24] www.indianmba.com

[25] Sahoo and Swarup Chandra, Problem of Industrial Labour in Orissa. Utkal University, 1972. pp 42-44.

[26] Ramrakhoan. Human aspect of work and productivity. Allied Publishers Pvt. Ltd., New Delhi, 1978 , pp. 62-64.

[27] Report of the Royal Commission on Labour in India, Government of India, 1931.

[28] Report of the sub-Committee on Labour, 1937, p 15.

[29] Report of the Labour Investigation Committee, Main Report, Government of India, Delhi, 1946,p8

[30] Report of the Committee of Labour Welfare, Government of India, 1969, pp 15-17.

[31] Report of the study team on Labour welfare, Government of India, 1960, pp 16-18. 